ISSN 2078-6441. Вісник Львівського університету. Серія географічна. 2013. Випуск 42. С. 204-220. Visnyk of the Lviv University. Series Geography. 2013. Issue 42. P. 204-220.

$551.432(477: 292.452)$

росл в р вчук, ом н н тюк, иросл в в ник, росл в омин

ьвівський н ціон льний університет імені в н вул. . орошенк , 41, 79000, м. ввів, кр їн

озглянуто особливості геологічної будови $\mathrm{T}$ рельєфу укр їнського фр гмент зон рм роських і енінських стрімч ків, розміщених н конт кті між овнішніми ( лішовими) і нутрішніми рп т ми. 'ясов но морфоструктурні відмінності т спільні риси рельєфу цих зон. ериторію, що відповід є смузі зон рм роських і енінських стрімч ків, розглянуто як окремий геоморфологічний регіон гірської ч стини кр їнських рп т - обл сть (підобл сть)

іжгірських улоговин і трімч кових п сом. бгрунтов но доцільність виділення і т ксономічний р нг цього геоморфологічного регіону, викон но його поділ н т ксономічні одиниці нижчого р нгу.

лючові слов : рм роські стрімч ки, енінські стрімч ки, кліпени, морфоструктур , геоморфологічн регіон ліз ція, кр їнські рп ти

території кр їнських рп т, як відповід є смузі тектонічних зон рм роських і енінських стрімч ків, у р зі геоморфологічного р йонув ння прийнято виділяти дв регіони:

1) р йон келястих п сом [22, 26], трімч кового скелястого низькогір'я [18], кель ( трімч ків) [15];

2) p йон ерезне- іпч нської ( вигорл тської) долини $[9,22,26]$ бо вигорл тського низькогір'я [18].

ерший геоморфологічний р йон, розміщений між долин ми рік ік і ересв , з числяють до геоморфологічної обл сті (підобл сті) олонинсько- орногірських

рп т, другий, розміщений з хідніше долини іки, - до обл сті (підобл сті) улк нічних рп т і міжгірних улоговин.

ш мет - н підст ві морфоструктурного н лізу рельєфу розглянути й обгрунтув ти доцільність виділення геоморфологічного регіону, який відповід в би зоні

рм роських і енінських стрімч ків, визн чити межі й в жливі озн ки цього регіону, обгрунтув ти його т ксономічний р нг i поділ н т ксономічні одиниці нижчого р нгу.

ивчення кліпенів (стрімч ків) розпоч ли в другій половині ст. встрійські геологи. окрем, пит нням походження стрімч ків присвячені пр ці . уер , . іхтгофен , . т х , . ейм йр , . ліг , . льт, . уер , . йнохи,

. п лович т ін. [2].

30-ті роки ст. геологічну будову к рп ття вивч ли чеські геологи. елик ув г тектонічному положенню в пнякових стрімч ків приділен в пр цях . ндрусов (D. Andrusov). ісля з кінчення ругої світової війни зусилля геологів

(C) р вчук ., н тюк ., в ник ., омин ., 2013 
рп тського регіону були об'єдн ні в рп то- лк нській геологічній соці ції. 1960 р. у н уковому збірнику м тері лів Vз’їзду рп то- лк нської соці ції опубліков но ст ттю . ндрусов “он утесов (клиппенов) в рп тской системе”. V з'їзді рп то- лк нської соці ції (1958) . ялов підтрим в позицію . ндрусов $з 1937$ р. [2], що трімч ков ( енінськ ) зон не є продовженням рм роської зони.

йв гоміший внесок у вивчення геологічної будови рм роських і енінських стрімч ків у 60-, 70- т 80-ті роки ст. зробив . руглов, т кож . руглов у спів вторстві 3 . мірновим т ін. чений 3 пропонув в [1, 23] у меж х зони рм роських стрімч ків виділити дві підзони - нутрішню ( он стирецьку) і овнішню ( еж нську).

цей же період дет льно вивч ли стр тигр фію відкл дів рм роської і енінської зон. н логією з юрськими відкл д ми рм роського крист лічного м сиву і зони енінських стрімч ків, т кож н підст ві численних зн хідок кор лів т іншої ф уни вік в пнякових брил еж нської підзони у соймульській світі прийнято як кімеридж-титон, i можливо, в л нжин [1]. ослідженнями . руглов , . узьмичевої, . ернов з'ясов но, що велику групу в пнякових стрімч ків у відкл д х соймульської світи треб з числяти до нижньої крейди (б рем- пт). отужність відкл дів соймульської світи ст новить 1300-1500 м. ивченням i н лізом п леобіоти уточнено вік юрських відкл дів енінської зони. ст ннім десятиріччям дет льному вивченню п леоорг нізмів присвячені пр ці . ещух . оц нюк, . ур ля [5, 14], які обгрунтув ли нову стр тигр фічну схему юрських відкл дів енінської зони.

другій половині ст. підтверджено т обгрунтов но висновки встрійських геологів щодо безкореневого походження юрських в пняків (велетенські олістоліти) трімч кової зони, які були перевідкл дені у крейдові т п леогенові відкл ди. езульт ти дет льного вивчення геологічної будови зони трімч ків містять численні звітні роботи пр цівників к рп тської [15].

р ктеристик рельєфу трімч кових зон у б г тьох публік ціях стосув л ся перев жно ділянок скелястих п сом н межиріччі ереблі- ересви [19, 20, 22]. еред різном ніття рельєфу цього регіону н йбільше ув ги приділяли к рстовим порожнин м [6, 7, 21], які н йповніше предст влені н межиріччі ереблі- ересви. к рстовоспелеологічним р йонув нням [21] територія трімч кових зон з числен до трімч кового р йону, у якому виокремлено дві смуги: івнічну ( рм роськ зон ), що простягнул ся від с. овге до хівського м сиву, т івденну ( енінськ, бо трімч ков , зон ), що простяг ється від еречин до ересви. осліджені печери об'єдн ні у дв м сиви: гольський і ерленого меню.

г льні х р ктеристики рельєфу н ведено т кож у л ндш фтозн вчих пр цях . еренчук $[19,20]$, який серед низькогірних л ндш фтів кр їнських рп т виділив стрімч ковий вид. о цього виду л ндш фту з числені території зони рм роських і енінських стрімч ків н межиріччях ереблі- ересви, т кож н межиріччях пшиці- опурки- осівської ж до кордону з умунією. тже, до цього виду л ндш фтів бул з лучен н йширш південно-східн ділянк он стирецької підзони

рм роських стрімч ків. ерев жн більшість дослідників цей м сив відносил повністю бо ч стково до рм роського крист лічного м сиву $[19,22]$ чи до видовецького м сиву і олотвинської улоговини [20]. 
викон ному . ельником [16] дет льному фізико-геогр фічному поділі кр їнських рп т н території изькогірно- трімч кової обл сті, у яку повністю включено тектонічні зони рм роських і енінських стрімч ків від б сейну орж ви до кордонів 3 умунією, виділено дв р йони ( ур'янський т гольський), в меж х р йонів - вісім підр йонів. окрем, у південно-східній ч стині он стирецької підзони рм роських стрімч ків виокремлено еликобичківський підр йон. . руглов [13], виділяючи морфогенні мезорегіони (л ндш фтні р йони), сумірні з геоморфологічними р йон ми т підобл стями, т кож ув ж в 3 потрібне виокремити не лише р йон стрімч кових гір, розміщений н межиріччі іки- пшиці, й новий мезорегіон пшицько- осівського низькогір'я, приурочений до н йширшої ч стини зони рм роських стрімч ків.

роведені к федрою геоморфології і п леогеогр фії ьвівського н ціон льного університету імені в н р нк колективні експедиційні дослідження (2009 і 2012 рр.) рельєфу улк нічного п см, рм роського м сиву, трімч кового регіону і олотвинської улоговини кр їнських рп т, т кож індивіду льні н пр цюв ння ії співробітників, д ли змогу зібр ти б г тий ф ктичний м тері л щодо морфоструктури, морфоскульптури, історії розвитку рельєфу, дин міки суч сних рельєфоутворюв льних процесів. езульт ти досліджень використ но під ч с н пис ння звітів з держбюджетних н уково-дослідних тем, т кож опубліков ні в моногр фіях і н укових збірник х [8-12].

собливості геологічної будови т рельефу зони рм роських стрімч ків. рм роські стрімч ки вузькою смугою простяг ються від 6 сейнів рік опурк i осівськ н сході-південному сході до долини р. ториця н північному з ході. ксим льну ширину (до 10 км) смуг рм роських стрімч ків м $є$ н межиріччях осівської- опурки- ересви, 3-6 км - н межиріччях ересви- ереблі- ікиорж ви, 1-3 км-н межиріччі орж ви- ториці (див. рис. 1).

в ж ють [23, 24], що тектонічній зоні рм роських стрімч ків 3 скл дністю будови нем є н логів не тільки в кр їнських рп т х, й 3 їхніми меж ми. стилем тектоніки і літолого-ф ці льними особливостями тут виділяють дв с мостійні покриви (підзони) - еж нський (зовнішній) і будові зони рм роських стрімч ків беруть уч сть флішові товщі п леогену, оточені із зовнішнього боку нефлішовими крейдовими товщ ми, у які включено величезні брили м сивних к рбон тних порід (див. рис. 2).

ежк нський покрив (н зв від г. еж - 933,5 м н межиріччі лої гольки i ереблі) вузькою смугою (400-500 м в околицях с. овге, близько 2 км н межиріччі орж ви- іки і до 4 км у долині ерешілки) простяг ється 3 північного 3 ходу н південний схід н відст нь до 40 км. долині іки ця смуг н короткому відтинку повністю перекрит он стирецьким покривом - тонкоритмічним флішем шопурської світи нижнього-середнього еоцену.

ідповідно, еж нський покрив перекрив $є$ хівський і місцями оркулецький флішові покриви (див. рис. 1, 2). межиріччі ереблі- лої і еликої гольокуж нки покрив густою системою поздовжніх, поперечних і ді гон льних розломів розділений н окремі брили, що д ло підст ву . руглову [23] тр ктув ти нижній структурний комплекс (докрейдовий і крейдовий) як скл дну моноклін ль-луску, з г льну структуру - як скл дний горст- нтиклінорій.

еред крейдових відкл дів, які беруть уч сть у будові еж нського покриву (геологічн к рт кр їнських рп т м сшт бу 1:200 000, 1977), домінують конгломер ти, пісковики, левроліти соймульської світи нижньої крейди, в пняки, ргіліти, туфи, 
3 рідкісними прош рк ми левролітів і пісковиків к м'янопотоцької світи нижньої крейди, червоні ргіліти з прош рк ми пісковиків пухівської світи верхньої крейди. межиріччі орж ви- іки у внутрішній ч стині покриву поширені еоцен-олігоценові відкл ди метівської світи (гр веліти, пісковики, левроліти, строк ті т чорні мергелі). еред екзотичних порід н йч стіше тр пляються верхньоюрські в пняки, т кож трі сові в пняки і м рмури, крейдові ді б зи, мезозойські серпентиніти, п леозойські гр нітоїди т ін. одо природи стрімч кових утворень є припущення [23], що всі породи - брили доб ремського віку, зокрем й екзотичні, $є$ різного розміру седимент ційними відторженцями обв льно-зсувного походження (олістоліт ми).

фронт льною ч стиною еж нського покриву пов'яз не поширення рм роських скель - стрімч ків. ут т кож зосереджені м ксим льні бсолютні й відносні висоти рм роської зони. ксим льні бсолютні висоти в б сейн х рік лої i еликої гольок перевищують 1000 м (у верхів'ях потоку менецький $-1095,9$ і 1 011,6 м; у верхів'ях потоку ребінський - 1006,4 м). р пляються вершини, які близькі до тисячників (г. ог р, 950,0 м; г. еж, 933,6 м). ксим льні відносні висоти н цих ділянк х колив ються в меж х 500-600 м. тже, 3 гіпсометричними пок зник ми цій ч стині еж нського покриву прит м нний середньогірний рельєф, решті його території від околиць с. овге н північному з ході до межиріччя уж нкиерешілки н піденному сході - низькогірний.

н йвищій ч стині території еж нського покриву перев ж ють круті $\left(15-17^{\circ}\right)$, дуже круті $\left(17-25^{\circ}\right)$ і н дзвич йно круті схили $\left(25-35^{\circ}\right)$. либоко вріз ні долини потоків м ють форму ущелин і тіснин. ут же зосереджен і н йбільш кількість скельстрімч ків, окремі з них досяг ють до 100 м довжини, 30-50 м ширини і 50-80 м висоти. їхній будові беруть уч сть юрські темно-сірі т рожеві тонкозернисті в пняки, у яких високий вміст кор лів. окремих місцях кор лові в пняки з мінені в пняковими брекчіями, які скл д ються з ул мків юрських кор лових в пняків [2]. цим регіоном пов'яз ний комплекс к рстових форм рельєфу, зокрем підземного к рсту. ут виявлено й опис но десятки печер $[6,7,21]$. оверхневі форми к рстового рельєфу предст влені к р ми, які приурочені до урвищних схилів окремих стрімч ків,

т кож до ділянок схилів, скл дених в пняк ми, в пняковими брекчіями. сто т кі ділянки тр пляються в б сейн х потоків мінський (пр в приток еликої гольки), ребінський (лів приток лої гольки).

он стирецький покрив (н зв від с. он стирець н пр вобережжі іки) 3 йм є внутрішню ч стину зони рм роських стрімч ків. уцільною смугою він простяг ється від рм роського крист лічного м сиву до долини р. ториця н $80 \mathrm{KM.} \mathrm{Його} \mathrm{будові}$ беруть уч сть і виходять н поверхню тільки п леогенові відкл ди, які утворюють велику, ускл днену дрібною скл дч стістю і розривними дислок ціями моноклін ль із з г льним 3 нуренням н південний з хід під н сунуту н неї зону енінських стрімч ків [23].

будові південно-східної ч стини підзони (б сейн р. опурк, верхня ч стин 6 сейну p. пшиця) беруть уч сть відкл ди шопурської світи, предст влені тонкоритмічним сіро-зеленим флішем, п чк ми строк тоб рвних глинистих відкл дів і м сивними пісковик ми нижнього-середнього еоцену. ля цієї ділянки $€ \mathrm{x} p$ ктерним низькогірний рельєф з перев жними бсолютними висот ми 450-750 м, відносними 150-250 м (відносно днищ долин головних рік), усередненою густотою горизонт льного розчленув ння рельєфу 1,6-3,2 км/Км². ростежується поступовий сп д бсолютних висот у північно-з хідному н прямі до олотвинської улоговини і зрост ння їх н південний схід до рм роського крист лічного м сиву. 


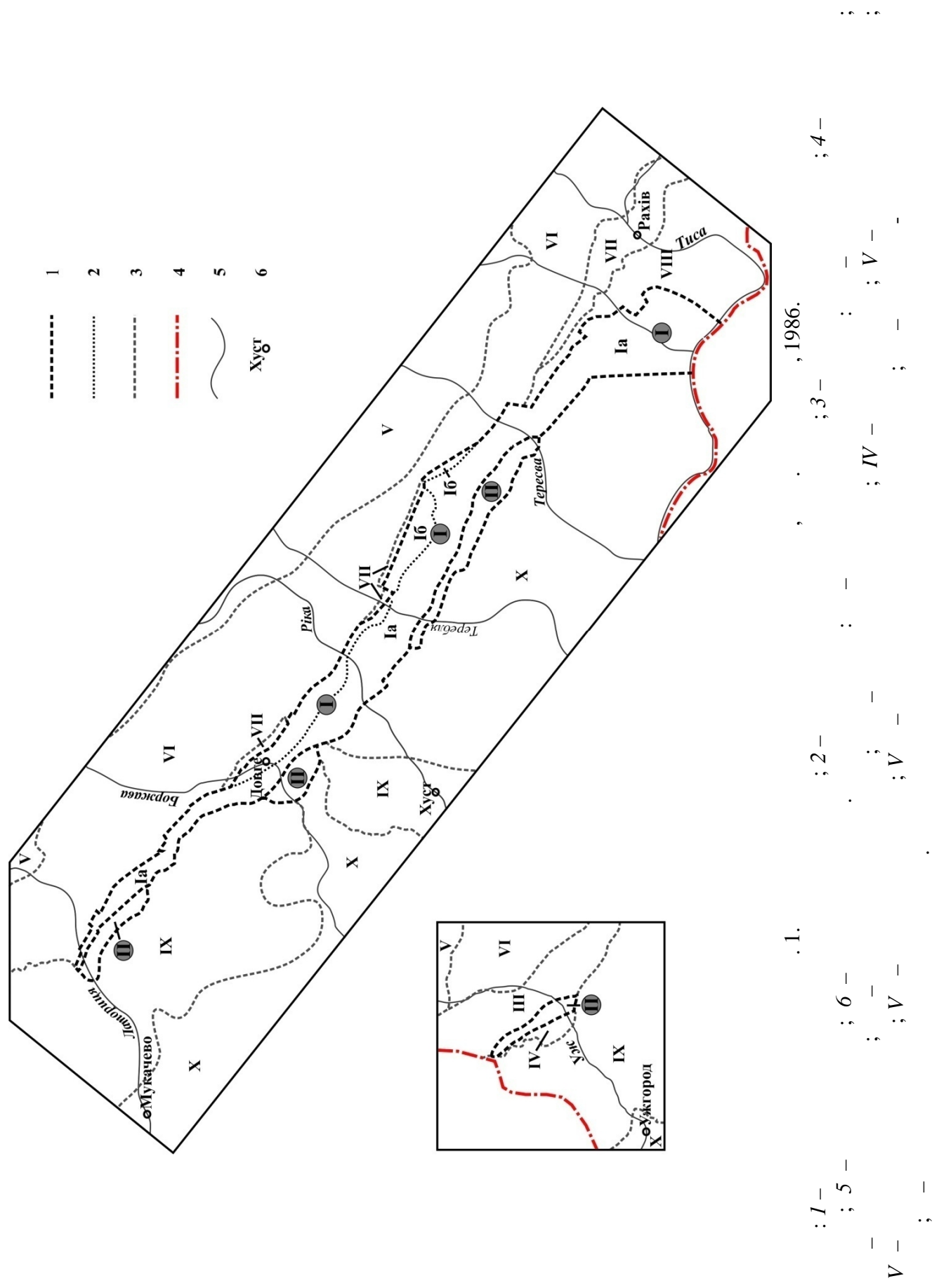




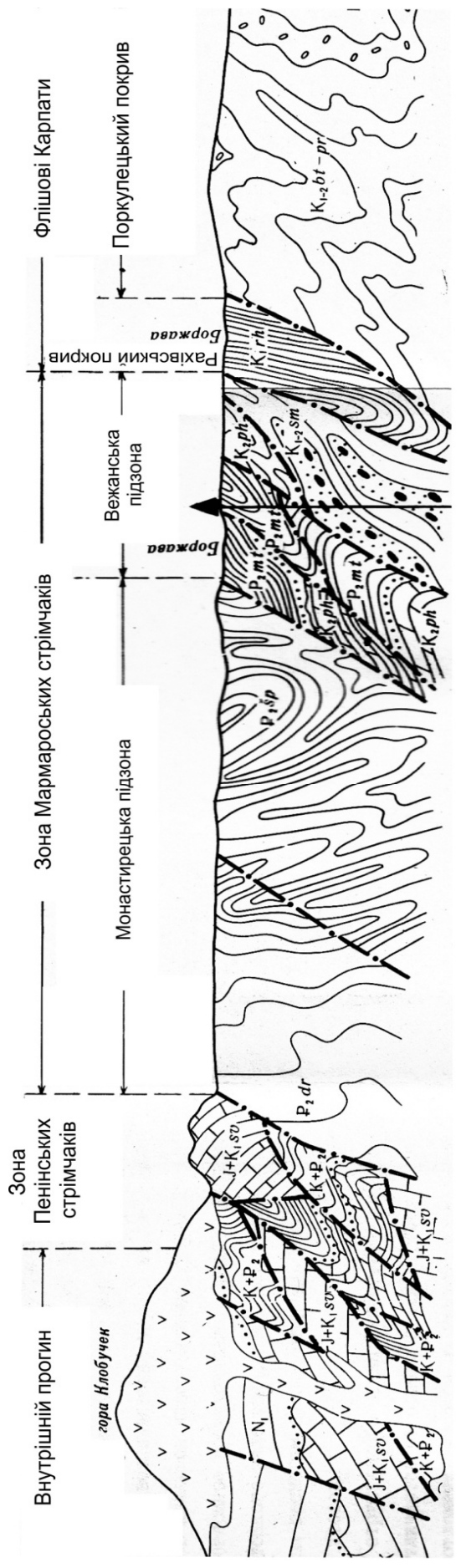

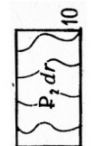
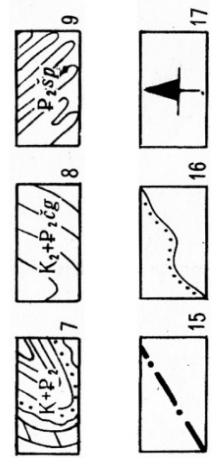

(1)
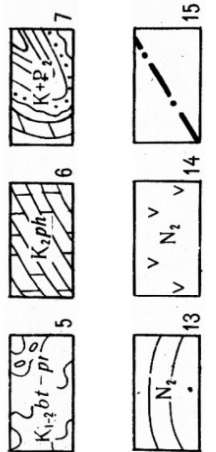

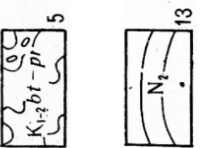

D.
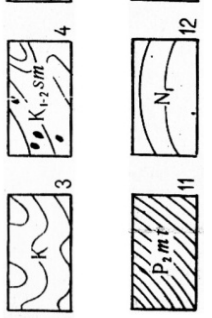

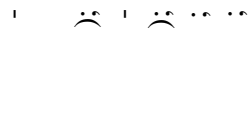

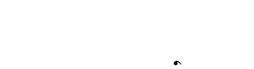

ڤ.

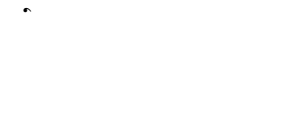

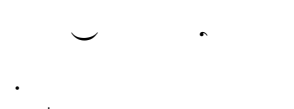

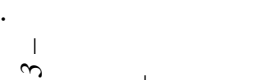

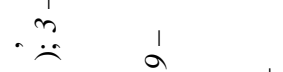

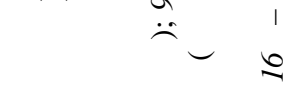

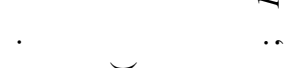

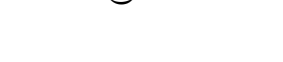

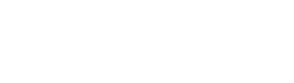

ㅌ.

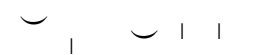

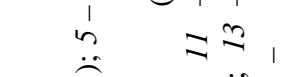

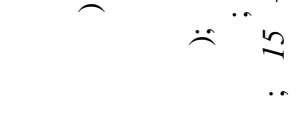

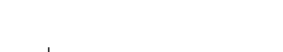

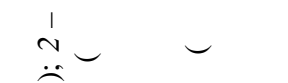

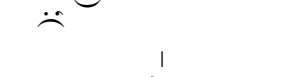

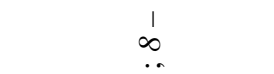

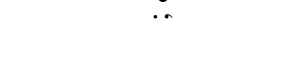

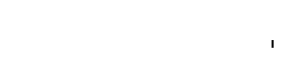

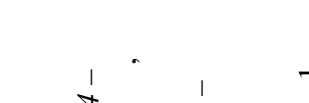

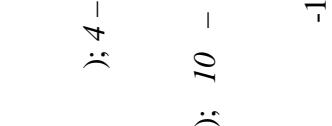

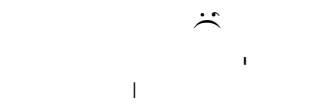

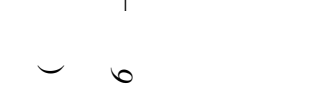

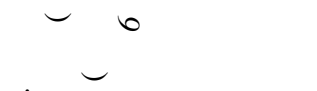

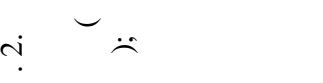

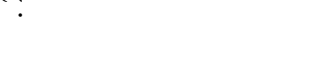

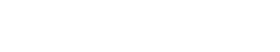

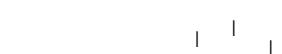

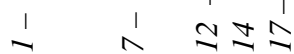


ксим льні бсолютні висоти н межиріччі осівської- опурки ст новлять 831,0 (г. левк ), 614,8 м (г. олязин), н межиріччі опурки- пшиці - 831,0 (г. учок), 722,8 м (г. тоуб) у південній ч стині й пон д 1000 м у північній (г. унгу, 1020,5 м).

ід околиць с. лини он стирецький покрив н був є “К рп тського” простяг ння - південний схід-північний з хід. його будові з'являються відкл ди верхньогосереднього еоцену (др гівськ світ ), предст влені пісковик ми з рідкісними флішовими п чк ми, гр веліт ми і конгломер т ми. межиріччі ересви- еликої і лої гольок- ереблі ці відкл ди перекриті енінським покривом і ширин он стирецького покриву тут дещо менш .

бидві смуги відкл дів (шопурської і др гівської світ), які беруть уч сть у будові он стирецької підзони, простежуються від околиць с. лини в долині р. ересви до околиць с. ушниця в долині орж ви. північно-з хідному н прямі до долини p. ториця ці відкл ди змінюються п леоцен-еоценовим флішем, серед якого вздовж конт кту 3 оркулецьким покривом лішових рп т тр пляються мікром сиви нерозчленов них крейдових відкл дів.

р ктерною рисою рельєфу он стирецького покриву між долин ми ересви i ториці $€$ н $б$ г то більш, ніж у 6 сейні опурки, густот горизонт льного розчленув ння, як колив ється в меж х 2,8-3,6 км/км². межиріччі ерешілкиуж нки- еликої і лої гольки- ереблі поміж енінською зоною і еж нською підзоною усереднен горизонт льн розчленов ність у он стирецькій підзоні збільшується до $4,0-4,8 \mathrm{KM} / \mathrm{KM}^{2}$. н чн густот горизонт льного розчленув ння пов'яз н тут з великою кількістю поперечних приток головних рік, які т кож м ють сильно розг лужену мережу приток нижчого порядку.

либин вертик льного розчленув ння он стирецької підзони між долин ми ересви т ториці колив ється в меж х 150-450 м. йбільші відносні висоти (450-500 м) в меж х он стирецького покриву з фіксов ні н межиріччях ерешілки- уж нки- еликої гольки- лої гольки.

олини рік уж нки т обох гольок вузькі, з одною, зрідк двом н дз пл вними тер с ми, які тр пляються фр гмент ми. перетині енінської зони і еж нської підзони долини цих рік м ють вигляд ущелин, н окремих ділянк $\mathrm{x}-$ тіснин.

межиріччях лої гольки- ереблі- іки х р ктер рельєфу дещо змінюється. кщо горизонт льне розчленув ння з лиш ється приблизно т ким же, як і в південносхідній ч стині он стирецької підзони (2-4 км/км²), то пок зники вертик льного розчленув ння знижуються до 150-300 м. ксим льні бсолютні висоти н межиріччі

лої гольки- ереблі ст новлять 691,0 м (г. ичерел ), н межиріччі ереблі- іки 642,2 (г. юрюк), 638,7 м (г. іл).

олини головних рік 6 сейну ереблі і іки, перетин ючи смугу тонкоритмічного флішу шипотської світи, зн чно розширюються. ирин долини ереблі між сел ми p гове i брідь ст новить 5-8 км, долини іки між сел ми он стирець і ерезове - 5-10 км. цих ділянк х долин простежується фр гмент ми н обох берег х комплекс із чотирьох-п'яти н дз пл вних тер с, відносні висоти яких ст новлять 1,5-3,0, 4-8, 15-20, 30-40 і пон д 50 м. йбільш площ прип д $\epsilon$ н поверхні першої і другої н дз пл вних тер с.

межиріччі іки- орж ви- ториці в меж х рм роської тектонічної зони можн виділити дві ділянки, які докорінно відрізняються 3 х р ктером геологічної будови і морфологічними особливостями рельєфу. 
ерш ділянк з йм є межиріччя іки- орж ви і невелику ділянку н пр вобережжі р. орж ви від с. овге до околиць с. ушниця. північний з хід від с. овге еж нський покрив виклинює, відкл ди др гівської і шопурської світ п леогену он стирецького покриву виклинюють в околицях с. ушниця.

руг ділянк он стирецького покриву розміщен н північному з ході і простяг ється вузькою смугою до долини ториці. ï будові беруть уч сть нерозчленов ні відкл ди п леоцену-еоцену, предст влені піщ но-глинистим сірим і строк тим п леоцен-еоценовим флішем.

рельєфі першої ділянки н пр вобережжі іки досить вир зно фіксов ний конт кт не лише між еж нською і он стирецькою підзон ми, й між ділянк ми он стирецької підзони, які сформув лися н відкл д х шопурської і др гівської світ. ксим льні бсолютні висоти зосереджені н північ від с. ерезове у еж нській підзоні i ст новлять 738,7 (урочище р сино), 667,1 м (г. рислоп). отоки япедник, сено, еховий і отік розчленовують цей м сив вузькими ущелиноподібними долин ми.

ериторія он стирецької підзони н межиріччі іки- орж ви розділен меридіон льними долин ми еховця, елов, отоку (притоки р. іки) н вузькі м сиви з перев жними бсолютними висот ми від 350 до 500 м. ділянк х, які приурочені до смуги др гівських пісковиків, долини численних потоків вузькі, з крутими і дуже крутими (20-25 і більше) схил ми. ділянк х поширення тонкоритмічного флішу шопурської світи долини потоків ст ють розлогішими, крутість схилів зменшується.

ід долини іки он стирецьк підзон у північно-з хідному н прямі поступово звужується від 6 до 4-2 км у долині орж ви, н відрізку від вододілу орж ви- іки (околиці с. ипецьк олян ) до долини ториці - від 2 км до 400-600 м. p йоні орж ви он стирецьк підзон перекрит зоною енінських стрімч ків і вулк нічними пород ми игорл т- утинського п см. н прямі до долини р. ториця це перекриття збільшується.

околицях с. овге м ксим льні бсолютні висоти у еж нській підзоні перевищують 400 м (г. ис , 409,2 м - межиріччя орж ви і винки). он стирецькій підзоні вони поступово збільшуються у північно-3 хідному н прямі від 262,2 (г. бл з) до 477,7 м н межиріччі потоків винки і м’яного т до 506,5 (г. нилий ерх) і 589,5 м (г. утов ) в околицях с. осош - біля вододілу між 6 сейн ми ториці і орж ви.

ід околиць с. ерецьки до околиць м. в ляв он стирецьк підзон простежується в рельєфі у вигляді вузького зниження, витягнутого вздовж долини р. усинк (ч стин д вньої ерезне- іпч нської бо ур'янської поздовжньої долини). південному з ході вон конт ктує 3 енінськими стрімч к ми (від околиць м. в ляв до околиць с. тройне) i игорл т- утинським вулк нічним м сивом. ксим льні бсолютні висоти колив ються тут у меж х 300-400 м (г. л й, 428,0 м, розміщен в околицях с. усин ).

собливості геологічної будови т рельєфу зони енінських стрімч ків. он енінських стрімч ків, бо енінський стрімч ковий пояс, розмежовує нутрішні i овнішні (лішові) рп ти. території кр їни енінські стрімч ки є шовною зоною між лішовими рп т ми і к рп тським прогином, через що б г то дослідників ототожнює її із зоною к рп тського глибинного розлому [23, 24]. кр їнських рп т х відкл ди енінського стрімч кового поясу лок льно виходять н земну поверхню в долин х рік ж, ториця, орж в, т кож н йдовшим фр гментом від межиріччя іки- ереблі до долини р. ересв. ирин смуги в долин $\mathrm{X}$ ж 
ториці ст новить 0,5-2,0 км, довжин - 11-13 км, в долині орж ви, відповідно, 0,3-3,0 і 9-10 Kм.

йдовший фр гмент зони від межиріччя устця- ереблі до долини ересви простежується смугою з вширшки 0,3-3,0 км н 31 км. північно-з хідній ч стині цієї смуги н межиріччі ереблі- устця 3 енінською зоною пов'яз ний невисокий хребет (з хідного-північно-з хідного простяг ння від с. p гове) 3 бсолютними висот ми 591,6, 586,4 і 575,2 м. івденно-з хідні схили сильно розчленов ні верхів'ями p. йлов і притокою р. устець унки. івнічно-східні схили менше розчленов ні, одн к зн чно крутіші $\left(18-20^{\circ}\right)$. ідносні висоти колив ються в меж х 220-260 м.

будові хребт беруть уч сть строк ті мергелі і фліш нижньої крейди, у яких тр пляються включення в пняків св лявської світи верхньої юри-нижньої крейди і в пняків т доломітів трі су. північно-з хідній ч стині м сиву н невеликій площі поширені відкл ди вільховчицької світи.

бсолютні т відносні висоти поступово зрост ють у південно-східному н прямі.

межиріччях ереблі- еликої гольки низькогірні м сиви хоч й зберіг ють “к рп тську” морфоструктурну орієнт цію (північний з хід-південний схід), одн к долин ми меридіон льного простяг ння розділені н витягнуті з півночі н південь м сиви (хребти). межиріччі ереблі- лої гольки низькогірний м сив еликого олу- зової ичери з м ксим льними бсолютними висот ми від 556 до 663,0 м (г. зов ичер ) розділений меридіон льними долин ми д рів i ривця н три м сиви: еликого олу, зової ичери і невеликий хребет он стир. ксим льні відносні висоти щодо головних рік ст новлять 250-300 м.

оміж долин ми обох гольок зоні енінських стрімч ків відповід є н йбільш звужен ч стин межиріччя. руті (пон д 20) схили до обох долин розчленов ні короткими, ле глибоко вріз ними долин ми потоків. нівне положення н межиріччі 3 йм є м сив з вершиною ермокс $(686,5$ м), відносн висот якої н д руслом лої гольки ст новить $360 \mathrm{M}$.

будові межиріч ереблі- лої гольки- еликої гольки провідну роль відігр ють нерозчленов ні відкл ди верхньої-нижньої крейди (строк ті мергелі, фліш), серед яких невеликими м сив ми місцями виступ ють в пняки середньої т верхньої юри, т кож світло-сірі ш рув ті в пняки з кременями св лявської світи (верхня юр -нижня крейд ).

уттєво змінюється х р ктер рельєфу у енінській зоні н межиріччях еликої гольки- уж нки- ерешул ( ерешілки)- ересви. е вже помітно н віть з рисунк орогідрогр фічної мережі. йже всі притоки цих рік м ють н прям, близький до широтного, гірські хребти, хоч й м ють численні відг луження, іноді звивисті, проте з г лом витримують “к рп тський” н прям (північний 3 хід-південний схід).

більшій ч стині території цих межиріч поширені відкл ди вільховчицької світи еоцену (б з льні конгломер ти, гр веліти, пісковики, тонкоритмічний фліш), серед яких місцями відслонені крейдові в пняки. руге місце 3 площею поширення н лежить смуг м строк тоб рвних відкл дів крейди, у які вкр плені невеликі ділянки з юрськими в пняк ми і доломіт ми.

межиріччі еликої гольки- уж нки м ксим льну бсолютну висоту м $е$ г. ерезников т ичер (851,9 м), від якої у північно-з хідному, з хідному і південносхідному н прям х відходять хребти, шо слугують вододіл ми між долин ми потоків ункульського, льнього, рпіновського. хні висоти поступово знижуються від г. ерезников т ичер до долини еликої гольки до 772,4, 726,0, 581,5, 585,1 м. 
схід і південний схід від ерезников тої ичери до долини уж нк короткі крутосхилі (пон д 22 $2^{\circ}$ ) хребти знижуються до 777,5 і 732,0 м. ідносне перевищення ерезников тої ичери н д руслом р. уж нК ст новить 490 м. есь цей м сив густо розчленов ний глибоко вріз ними приток ми уж нки і потоку иновець. півдня головні хребти розчленов ні верхів'ями угу т ільховчик . осить зн чн глибин вертик льного розчленув ння межиріччя еликої гольки- уж нки не лише щодо головних рік, й щодо численних потоків. еревищення водолільних хребтів н д русл ми потоків ункульський і льній колив ється в меж х 210-345 м. устот розчленув ння тільки постійними водоток ми сяг є 4-9 км/км².

о південно-східної ділянки енінських стрімч ків н межиріччі уж нкиерешул ( ерешілки) приурочені м ксим льні бсолютні висоти. оловний хребет північно-з хідного-південно-східного простяг ння фіксов ний вершин ми 766,0 (н лівобережжі умш нецького потоку, з півтор кілометр від русл уж нки), 872,3 (г. ерх олянський), 844,0 м ( ерлений мінь). ксим льні відносні висоти ст новлять 518-522 м.

будові північно-східної ч стини межиріччя (н конт кті з др гівською світою

он стирецької підзони) перев ж ють відкл ди вільховчицької світи еоцену, серед яких тр пляються острівки нерозчленов них відкл дів крейди і терешульських конгломер тів неогену, південно-з хідної - строк тоб рвні відкл ди нижньоїверхньої крейди, які чергуються з відкл д ми вільховчицької світи.

евеликі фр гменти енінської зони, розміщені в б сейн х орж ви, ториці т ж , межують з вулк ногенними товщ ми игорл т- утинського п см .

йбільш 3 площею приборж вськ ділянк зони м є ширину вздовж долини орж ви близько 3 км, м ксим льну довжину - 10 км. ерев жні бсолютні висоти н пр вобережжі ріки колив ються в меж х 250-300 м (г. остр , 294 м), н лівобережжі 250-400 м. ксим льні відносні висоти н д руслом орж ви ст новлять 120-150 м. p вобережний і лівобережний м сиви розчленов ні долин ми численних протоків, які орієнтов ні перев жно у “к рп тському” н прямі. будові північної ч стини ділянки беруть уч сть нерозчленов ні крейдові відкл ди, серед яких є острівки верхньоюрських в пняків (н лівобережжі орж ви) і в пняків т доломітів юри й трі су н пр вобережжі р. орж в . південній смузі ділянки домінують верхньо- і нижньокрейдові строк тоб рвні відкл ди, які від північної ділянки н лівобережжі орж ви відділені вузькою смугою юрських в пняків. лівобережній ч стині м сиву розміщений риборж вський к р'єр м рмуризов них в пняків.

в лявськ ділянк енінських стрімч ків вузькою смугою (0,5-2,0 км) простяг ється з північного з ходу н південний схід уздовж околиць с. p чине - м. в ляв c. ерник - с. тройне - c. опуш нк . ротяжність смуги - пон д $1 \mathrm{kм} \mathrm{н} \mathrm{пр} \mathrm{вобе-}$ режжі ториці і 10-11 км н лівобережжі. ксим льні бсолютні висоти колив ються в меж х 325-355 м, м ксим льні відносні висоти (від русл р. усинк ) - від 110 до 130 м. будові ділянки беруть уч сть нерозчленов ні крейдові відкл ди, серед яких в околицях в ляви, ерник і тройного тр пляються острівки юрських в пняків. рім того, між сел ми ерник і тройне є невеликий м сив відкл дів вільховчицької світи, н схід від с. тройне - в пняки св лявської світи (верхня юр -нижня крейд ).

еречинськ ділянк енінських стрімч ків у долині р. ж шириною 0,3-2,0 км 3 північного з ходу н південний схід простяг ються н $11 \mathrm{kM.}$ всій протяжності в її будові перев ж ють нерозчленов ні відкл ди крейди, серед яких тр пляються невеликі острівки в пняків верхньої і середньої юри. будові південно-східної ч стини ділянки, 
крім крейдових відкл дів, поширені конгломер ти, пісковики і тонкоритмічний фліш вільховчицької світи (південн смуг ). оміж відкл д ми крейди і вільховчицької світи розміщений м сив вулк нітів гутинської світи. ксим льні бсолютні висоти в околицях с. овоселиця колив ються в меж х 300-500 м, поступово знижуючись до долини р. ж.

еоморфологічне р йонув ння. огляду н підготовку моногр фій із з поч тков ної к федрою серії “ ельєф кр їни”, у яких кожній геоморфологічній обл сті (підобл сті) кр їнських рп т присвячен окрем публік ція, н зріл необхідність визн читись із геоморфологічним поділом території, якій відповід ють зони енінських і рм роських стрімч ків, рм роський крист лічний м сив т обл сть к рп тського внутрішнього прогину. освід дет льного геоморфологічного р йонув ння цієї місцевості, н бутий у ході вивчення рельєфу улк нічного п см кр їнських

рп т [9] і олотвинської улоговини [11, 12] з свідчив, що особливо проблемним пит нням є визн чення місця у схемі геоморфологічної регіон ліз ції обл сті поширення зон енінських і рм роських стрімч ків.

кщо дотримув тися уст лених принципів геоморфологічної регіон ліз ції гірських кр їн і структурно-денуд ційних рівнин, згідно з якими т ксономічні одиниці р нгу обл сті, підобл сті, ч сто і р йону виділяють 3 морфоструктурними озн к ми, вр ховуючи їхню приуроченість до регіон льних і субрегіон льних тектонічних одиниць, т взяти до ув ги суч сні схеми геоморфологічного р йонув ння гірської ч стини кр інських рп т, у яких обл стям (львівські геоморфологи . ись т ін.) чи підобл стям (київські геоморфологи . лієнко т ін.) [18] з звич й відповід ють тектонічні зони, покриви і системи покривів, то зон м рм роських і енінських стрімч ків м л б відповід ти певн геоморфологічн обл сть бо підобл сть.

ур хув нням принципу сумірності, відповідно до якого регіони певного т ксономічного р нгу, виділені у меж х рівнинних бо гірських територій, м ють бути сумірними 3 площею, територію, що відповід є смузі тектонічних зон рм роських і енінських стрімч ків доцільно розгляд ти як с мостійну трімч кову підобл сть (обл сть) гірської ч стини кр їнських рп т.

г д ємо, що зону енінських стрімч ків не лише з числяють до регіон льних тектонічних одиниць, й розгляд ють як в жливий тр нск рп тський елемент, який н всій протяжності зберіг є х р ктерні риси тектоніки т стр тигр фічного розрізу. кщо в меж х кр їни є порівняно вузьке південно-східне з кінчення зони, то від кордону зі лов ччиною вон тягнеться ще н 500 км, іiі ширин досяг $€$ кількох десятків кілометрів [23].

он рм роських стрімч ків просторов т генетично пов'яз н 3 рм роським крист лічним м сивом, одн к 3 будовою приповерхневої ч стини земної кори суттєво відрізняється від нього. окрем, п леогенові відкл ди зони рм роських стрімч ків суттєво відрізняються в нижній (метівськ світ еж нської підзони) і верхній (др гівськ світ он стирецької підзони) ч стин х розрізу від п леогенових відкл дів крист лічного м сиву [20].

е менш суттєві відмінності відрізняють зону рм роських стрімч ків від суміжних покривів овнішніх ( лішових) рп т, скл дених нижньокрейдовим флішем.

йд внішими серед корінних утворень у еж нській підзоні цієї зони є крейдові відкл ди соймульської світи, у яких нем типових флішових озн к [20]. е є флішовим утворенням і відкл ди пухівської світи. лішовий ет п розвитку зони рм роських стрімч ків пов'язують з ярмуцькою світою к мп н-м стрихтського віку. 
рм роські стрімч ки з окр їною рм роського м сиву ф ктично вклинюються між хівським т оркулецьким покрив ми овнішніх рп т $\mathrm{i}$ енінськими стрімч к ми (див. рис. 1). тже, вони через перехідну зону ( енінські стрімч ки) ніби дочленовуються до з хідного сегмент нутрішніх рп т [20], їхня спільн історія пов'яз н із зоною глибинного розлому д внього з кл д ння.

ро недоцільність приєдн ння території трімч кових зон до олонинськоорногірського геоморфологічного регіону, приуроченого до внутрішніх флішових покривів овнішніх рп т, свідч ть не тільки особливості їхньої геологічної будови, й х р ктерні риси рельєфу. е менше підст в для з числення території трімч кових зон до тих геоморфологічних регіонів, які відповід ють рм роському крист лічному м сиву т мол совому к рп тському прогину.

огляду н 3 зн чені вище геолого-геоморфологічні особливості території, розміщеної в р йоні зон рм роських і енінських стрімч ків, т 3 дотрим ння морфоструктурного принципу геоморфологічного р йонув ння рп т не можемо погодитись 3 втор ми [3, 4], які н йширшу південно-східну ділянку трімч кової зони p йон келястих п сом - розділили між обл стю олонинсько- орногірських рп т і олотвинською улоговиною ( олотвинським низькогір'ям).

нше проблемне пит ння, пов'яз не з геоморфологічним р йонув нням території, як відповід є смузі тектонічних зон рм роських $і$ енінських стрімч ків, стосується поділу трімч кової обл сті кр їнських рп т н геоморфологічні регіони. йяскр вішою спільною, водноч с і специфічною рисою рельєфу обох зон $\epsilon$ н явність вир зно відособлених літоморфних ост нців, у тім числі скель, скл дених перев жно юрськими в пняк ми, у брил х яких утворилися численні печери.

вого ч су . ись [26], н лізуючи морфоструктуру кр їнських рп т, виділив морфоструктуру ерезне- іпч нської ( ур'янської) міжгірської тектоніко-ерозійної долини, що сформув л ся в зоні к рп тського глибинного розлому, до якого приурочен смуг стрімч ків (кліпенів). . іллер і . едірко [17] в фізико-геогр фічному р йонув нні кр їнських рп т н відповідній ділянці виділили “ изькогірнострімч кову обл сть". годом схему поділу цього регіону уточнив і дет лізув в . ельник [16]. в ж ємо, що с ме у цих схем х н йліпше відобр жено місце рм роських і енінських стрімч ків у геоморфологічній і фізико-геогр фічній регіон ліз ціях.

еоморфологічну регіон ліз цію обл сті іжгірських улоговин і трімч кових п сом, розроблену з ур хув нням геоморфологічного т фізико-геогр фічного поділів . ися [25, 26], . іллер , . едірк [17], . ельник [16], . руглов [13], пропонуємо в т блиці. ведемо т кож стислу описову х р ктеристику з пропонов ного поділу цього регіону.

жоцько- орж вськ міжгірськ улоговин (як ч стин виділеної . исем [26] ерезне- іпч нської міжгірської долини) з йм $є$ вузьку смугу між олонинським флішовим м сивом ( овнішні рп ти) н півночі-північному сході і улк нічним п смом н півдні-південному з ході. p йоні долини р. ж до бортів цієї улоговини з числен ділянк зон енінських стрімч ків і ідг ля, в долині ториці - ділянк зони енінських стрімч ків ( нутрішні рп ти). зн чимо, що формув ння зони ідг ля, як і трімч кової зони, тісно пов'яз не з глибинним розломом домезозойського $з$ кл д ння [23]. суч сному рельєфі розміщення улоговини виокремлене долин ми субсеквентних рік ур'я, іня і усинк. морфогенетичними озн к ми пї можн розділити н дв підр йони: ур'янсько- енінський і усинський. ерший 3 йм є 
межиріччя ж - ториці, другий - p йон долини p. усинк . ідрізняються ці ч стини долини тим, що ур'янсько- усинськ більше розроблен, ніж усинськ . рім того, у будові усинської ділянки беруть уч сть п леогенові відкл ди он стирецької підзони рм роських стрімч ків, які з літологічним скл дом подібні до відкл дів шопурської світи.

еоморфологічн регіон ліз ція обл сті іжгірських улоговин і трімч кових п сом

\begin{tabular}{|c|c|c|}
\hline Йон & ідр йон & ікрор йон \\
\hline \multirow{2}{*}{$\begin{array}{l}\text { 1. жоцько- орж вськ } \\
\text { міжгірськ улоговин }\end{array}$} & 1.1. ур'янсько- інійський & $\begin{array}{l}\text { 1.1.1. еречинське стрімч - } \\
\text { кове низькогір'я }\end{array}$ \\
\hline & 1.2. усинський & $\begin{array}{l}\text { 1.2.1. в лявське стрімч кове } \\
\text { низькогір'я }\end{array}$ \\
\hline \multirow{2}{*}{ 2. трімч кове низькогір'я } & $\begin{array}{l}\text { 2.1. рм роських стрімч - } \\
\text { ків }\end{array}$ & \\
\hline & 2.2. енінських стрімч ків & $\begin{array}{l}\text { 2.2.1. риборж вське } \\
\text { стрімч кове низькогір'я }\end{array}$ \\
\hline $\begin{array}{l}\text { 3. осівсько- опурське } \\
\text { низькогір'я }\end{array}$ & & \\
\hline
\end{tabular}

обох підр йон х виділяємо мікрор йони: у ур'янсько- інійському - еречинський, у усинському - в лявський (див. рис. 3).

еречинський мікрор йон порівняно вузькою смугою простяг ється 3 північного 3 ходу н південний схід до долини р. ж. ельєф тут сформув вся н субстр ті енінської зони і зони ідг ля, як розмішен н південь. он ідг ля н лежить до обл сті розвитку сл бкодеформов ного еоценового флішоїдного комплексу і є лок льним виходом н поверхню донеогенової основи к рп тського прогину нутрішніх рп т [24].

в лявський мікрор йон, як і еречинський, приурочений до лок льного виходу н поверхню відкл дів енінської зони, які беруть уч сть у будові лівобережного борт усинської поздовжньої долини.

трімч кове низькогір'я порівняно вузькою смугою (2-8 км), простяг ється з північного з ходу н південний схід від околиць с. ушниця (б сейн р. орж в ) до околиць с. лини (б сейн р. ересв ). формув вся н субстр ті енінської і рм роської зон. івнічно-з хідн ділянк (н північний з хід від с. овге) р йону з кінчується т м, де ще відслонені відкл ди шопурської, др гівської т метівської світ он стирецької підзони рм роських стрімч ків, н півночі виклинює еж нськ підзон , н півдні розміщений риборж вський м сив енінської зони.

ід межиріччя орж ви- іки до долини ересви територія трімч кового р йону відповід $€$ он стирецькій підзоні рм роських стрімч ків, у якій відкл ди др гівської і шопурської світ м ють суцільне поширення. трімч ки еж нської підзони тр пляються тут фр гмент ми, н йдовший 3-поміж них 3 йм є межиріччя іки- уж нки. озміщен н південь смуг енінських стрімч ків простежується від межиріччя устця- ереблі до долини р. ересв .

трімч ковому геоморфологічному р йоні 3 морфоструктурними т морфоскульптурними особливостями рельєфу вир зно виділяються підр йони рм роських i енінських стрімч ків. о другого треб включити риборж вський мікрор йон (див. рис. 3). 


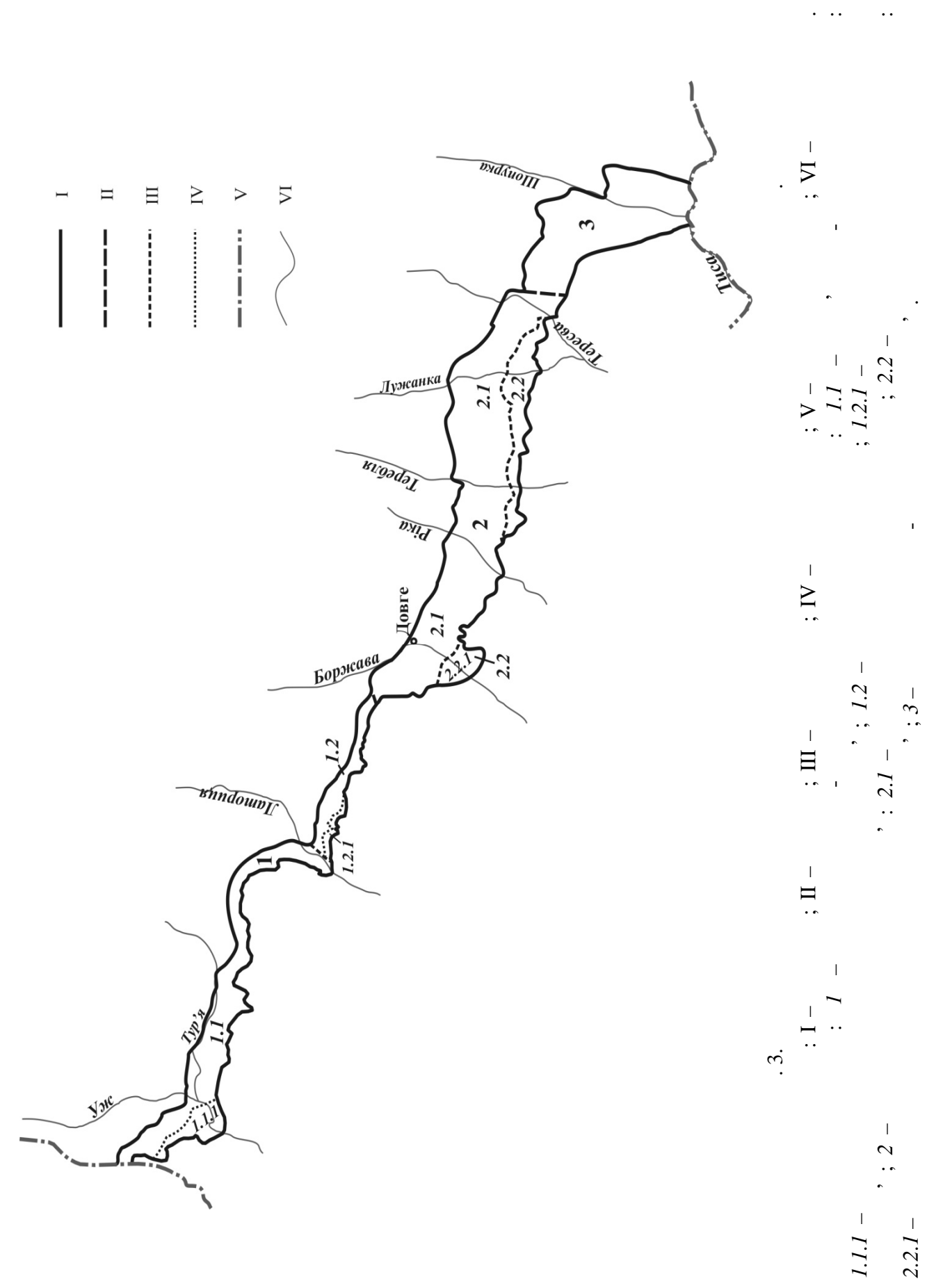


ежу між трімч ковим і осівсько- опурським р йон ми н йдоцільніше проводити н схід від с. лини вздовж лок льного розлому н лівобережжі ересви, де виклинюють відкл ди др гівської світи. південному сході ж до кордону 3 умунією у формув нні рельєфу он стирецької підзони беруть уч сть відкл ди тільки шопурської світи. уттєві відмінності в морфології, історії формув ння рельєфу д ють підст ви для виділення н цій ділянці осівсько- опурського р йону.

тже, беручи до ув ги геолого-геоморфологічні особливості території, що відповід є смузі зон рм роських і енінських стрімч ків укр їнського сегмент рп т, т дотримуючись морфоструктурного принципу геоморфологічного $\mathrm{p}$ йонув ння, ув ж ємо 3 доцільне виокремити іiі в окремий геоморфологічний регіон гірської ч стини кр їнських рп т - обл сть (підобл сть) іжгірських улоговин і трімч кових п сом. иділення цього геоморфологічного регіону т його поділ н головні субрегіони легко узгодити з суч сними схем ми фізико-геогр фічного р йонув ння кр їнських рп т.

1. еологическое строение и горючие ископ емые кр инских рп т // руды кр . . . : едр , 1971. -389 с.

2. еология . .48. рп ты. . . еологическое опис ние. - . : едр , 1966. $538 \mathrm{c.}$

3. ілецький . . риродно-геогр фічне р йонув ння кр їнських рп т як основ оптиміз ції природокористув ння у р йоні / . . ілецький // існик н ук. пр ць ернів. ун-ту. еогр фія. - 2012. - ип. 612-613. - . 28-32.

4. ілецький . олотвинське низькогір'я як геоморфологічн підобл сть к рп тського низькогір'я / ілецький, в’юк // сторія укр їнської геогр фії. - 2011. ип. 24. - . 60-65.

5. ои, нюк . . олюски і стр тигр фія юрських відкл дів енінської зони кр їнських рп т: втореф. дис. н здобуття н ук. ступеня к нд. геол. н ук / . . оц нюк. - ,, 2004. - 23 с.

6. ублянский . . рстовые пещеры кр ины / . . ублянский, . . ом ев. иев : ук. думк , 1980. - 180 с.

7. ублянський . . оходження т гідрогеологічні особливості глибинних к рстових порожнин кр їнських рп т/ . . ублянський, . . утов // риродні умови т природні ресурси кр їнських рп т.- .: ук. думк , 1968.- . 116-174.

8. $р$ вчук. еоморфологія олонинсько- орногірських рп т / . р вчук. ьвів : ид. центр ім. в н р нК , 2008. - 187 с.

9. $р$ вчук. ельєф улк нічного п см кр їнських рп т / . p вчук, . омин. - ьвів: ид. центр ім. в н р нк, 2011.-185 с.

10. pвчук. екре ційн оцінк рельєфу кр їнських рп т / . p вчук, . інько, . рус к, . н тюк, . ричевськ // роблеми геоморфології і п леогеогр фії кр їнських рп т і прилеглих територій : збірник н ук. пр ць. - ьвів : ид. центр ім. в н р нК , 2006. - .267-273.

11. $р$ вчук. еоморфологічн регіон ліз ція олотвинської ( ерхньотисенської) улоговини кр їнських рп т / . р вчук, . лик // роблеми геоморфології і п леогеогр фії кр їнських рп т і прилеглих територій : збірник н ук. пр ць. ьвів : ид. центр ім. в н р нК , 2012. - .329-339. 
12. $р$ вчук . ипологічні особливості рельєфу олотвинської ( ерхньотисенської) улоговини кр їнських рп т/ . р вчук, . лик // роблеми геоморфології і п леогеогр фії кр їнських рп т і прилеглих територій : збірник н ук. пр ць. ьвів : ид. центр ім. в н р нК , 2012. - . 318-328.

13. руглов . еліміт ція, метриз ція $\mathrm{T}$ кл сифік ція морфогенних екорегіонів кр їнських рп т/ . руглов // кр. геогр. журн. - 2008. - № 3. - . 59-68.

14. ещух . риборж вський к р’єр (геологія, генезис, структур , п леонтологія) : [ лектронний ресурс] / . ещух, . оц нюк, . ур ль / леонтологічний порт л “ ммонит ру”. - . 1-14. - ежим доступу: http://www.ammonit.ru/text/423.htm

15. цьків . . віт “ еологічне довивчення м сшт бу 1:200 000 хівської групи ркушів M-34-XXXVI, M-35-XXXI, L-34-VI, L-35-I н площі 12100 кв. км (19972006 рр.)" / . . цьків / к рп тськ , хідукргеологія. - 2006. - н. 1. $262 \mathrm{c.}$

16. ельник. кр їнські рп ти: еколого-л ндш фтозн вче дослідження / . ельник. - ьвів : ид. центр ім. в н р нк , 1999. - 285 с.

17. іллер . . рп ти кр їнські / . . іллер, . . едірко // еогр фічн енциклопедія кр їни. - ., 1990. - .2. - .113-114.

18. лієнко . . г льне геоморфологічне р йонув ння території кр їни / . . лієнко, . . рщевський, . . ортник [т ін.] // кр. геогр. журн. 2004. - № 1. - . 3-11.

19. рирод к рп тської обл сті / [з ред. . . еренчук ]. - ьвів : ид-во ьвів. ун-ту “ ищ школ ”, 1981. - . 48-61; 126-138.

20. рирод кр їнських рп т / [3 ред. . . еренчук ]. - ьвів : ид-во ьвів. ун-ту, 1968. - . .50-86; 208-238.

21. ідшу . рстовий морфогенез стрімч кового р йону ( кр їнські рп ти) / . ідуш // роблеми геоморфології і п леогеогр фії кр їнських рп т і прилеглих територій : збірник н ук. пр ць. - ьвів: ид. центр ім. в н 2008. - . .59-68.

22. удько . нженерно-геоморфологічний н ліз рп тського регіону кр їни / . удько, . р вчук. - ьвів: ид. центр ім. в н р нК, 2002.-171 с.

23. ектоник кр инских рп т: бъясн. з писк к тектон. к рте кр. рп т м-б 1:200 000 / [отв. ред ктор . . руглов]. - ьвов; иев : кр , 1986. - 152 с.

24. ектоническ я к рт кр инской и олд вской . сшт б 1:500 000: бъясн. з писк . - . : кр , 1988. - 133 с.

25. изико-геогр фическое р йониров ние кр инской / [под ред. . . опов , . . ринич ]. - .: зд-во иев. ун-т , 1968. - 683 с.

26. ись . . еоморфологія і неотектонік / . . ись // рирод кр їнських рп т / [з ред. . . еренчук ]. - ьвів : ид-во ьвів. ун-ту, 1968. - . 50-86. 


\title{
GENERAL FEATURES OF RELIEF OF MARMAROSHI AND PIENINY ROCKS OF UKRAINIAN CARPATHIANS AND THEIR PLACE UNDER SYSTEM OF GEOMORPHOLOGICAL REGIONALIZATION
}

\author{
Yaroslav Kravchuk, Roman Hnatiuk, Myroslav Ivanyk, Yaroslav Khomyn
}

Ivan Franko National University of Lviv,

P. Doroshenko Str., 41, UA-79000 Lviv, Ukraine

Peculiarities of geological structure and relief of Ukrainian fragment of zones of Marmaroshi and Pieniny rocks located between Outer (Flysch) and Inner Carpathians are considered. Morphostructural differences and common features of relief of these zones are clarified. Territory of zones of Marmaroshi and Pieniny rocks is considered as separate geomorphological region of mountain part of Ukrainian Carpathians - subregion of Intermountain Valleys and Rocky Chains. Expediency of separation and taxonomic class of this geomorphological region are proved, its division into taxonomic units of lower class is realized.

Key words: Marmaroshi rocks, Pieniny rocks, klippes (limestone rocks of Jurassic period), morphostructure, geomorphological regionalization, Ukrainian Carpathians.

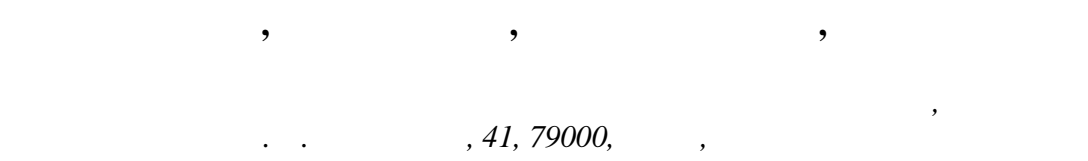

ссмотрено особенности геологического строения и рельеф укр инского фр гмент зон рм рошских и енинских утесов, р сположенных н конт кте между нешними ( лишевыми) и нутренними рп т ми. ыяснено морфоструктурные р зличия и общие черты рельеф этих зон. ерриторию, соответствующую полосе зон рм рошских и енинских утесов, p ссмотрено к к отдельный геоморфологический регион горной ч сти кр инских рп т обл сть (подобл сть) ежгорных котловин и тесовых гряд. боснов но целесообр зность выделения и т ксономический р нг этого геоморфологического регион, осуществлено его $\mathrm{p}$ зделение н т ксономические единицы низшего р нг .

лючевые слов : рм рошские утесы, енинские утесы, клипены, морфоструктур , геоморфологическ я регион лиз ция, кр инские рп ты. 